\title{
MANCHESTER AND SALFORD POLITICS AND THE EARLY DEVELOPMENT OF THE INDEPENDENT LABOUR PARTY
}

The grass-roots activities of the Independent Labour Party have been the subject of increased scrutiny from historians over the past few years, especially in the pages of this journal. ${ }^{1}$ Consequently we can now be a little surer about the contribution of the party to the development of an independent labour movement in Britain at the end of the nineteenth century, though with every fresh case-study a different local strategy seems to come to light. The one outstanding profile in this field is the closely observed account of the ILP in Bradford by J. Reynolds and K. Laybourn, who identify several key features in the party's growth in that city, notably the reformist nature of ILP socialism and the close associations with local trade unionism. "From the outset", they tell us, "Bradford trade unionism and the Bradford ILP were seen as two aspects of a single homogeneous labour movement aimed at the emancipation of the working class from poverty and exploitation." repeated elsewhere is a different matter. David Rubinstein's account of the ILP's intervention in the Barnsley bye-election of 1897, for example, reveals that the ILP in this area did not take up a Bradford-style policy of labour alliance until the late 1890's, and suggests that this was the case for the ILP as a whole. ${ }^{3}$ Yet studies of the party's activities on the other side of the Pennines indicate a different story still. N. Reid's short essay on the ILP

1 In the International Review of Social History, for example: Deian Hopkin, "The Membership of the Independent Labour Party, 1904-10: A Spatial and Occupational Analysis", XX (1975), pp. 175-97; J. Reynolds and K. Laybourn, "The Emergence of the Independent Labour Party in Bradford", XX (1975), pp. 313-46; David Rubinstein, "The Independent Labour Party and the Yorkshire Miners: The Barnsley By-Election of 1897", XXIII (1978), pp. 102-34. In the Bulletin of the North West Labour History Society (Manchester): S. Carter, "The Independent Labour Party in Ashton-under-Lyne, 1893-1900", No 4 (1977-78), pp. 63-91; N. Reid, "Manchester and Salford ILP: A more controversial aspect of the pre-1914 era". No 5 (1978-79). pp. 25-31.

2 Reynolds and Laybourn. "The Emergence of the Independent Labour Party in Bradford", p. 346.

3 Rubinstein, "The Independent Labour Party and the Yorkshire Miners", passim. 
in Manchester points to a continuing socialist tradition among ILP'ers in that city which frequently brought them into conflict with their comrades in other areas, whilst S. Carter's analysis of nearby Ashton-under-Lyne allots a very minor role indeed to the ILP in the development of independent politics. ${ }^{4}$

The present essay is offered as a means of taking this question of ILP strategy further by investigating the ILP's part in the politics of Manchester towards the end of the century. In one sense the essay simply seeks to extend our knowledge of the ILP in that city: considering Manchester's significance in the early socialist movement, especially as the birthplace of the Clarion, it has been surprisingly neglected. But additionally it is hoped that the following pages will help to complement the study of Bradford by Reynolds and Laybourn, and thus provide a comparison of ILP strategy and ideology between what were probably the two most important centres of socialism in the North of England at this time.

By 1910 Manchester possessed one of the most effective centralised labour parties in the country: in municipal and parliamentary politics labour was a force of some significance. The rise of labour to this position had been a comparatively rapid process, with few signs in the 1880's that an independent working-class party would develop and pose a threat to the established alignment of forces. Manchester's reputation as a radical city had seemed at that time to be in danger of melting away: from the 1850's the city where Stephens had preached Chartism to multitudes on Kersall Moor and where, according to Engels, was to be found "the seat of the most powerful Unions, the central point of Chartism [and] the place which numbers most Socialists" 5 had acquired a docile appearance. In place of its working-class radicalism and the strident bourgeois philosophy to which Manchester had given its name, the city had become increasingly noted for its Toryism both among the bourgeoisie and the workers. "Manchester", observed the Methodist Times in 1895, with a somewhat exaggerated sense of nonconformist gloom, "seems to be completely under the thumb of liquor and clericalism." 6

To some extent this transformation in the city's political temper was an effect of its changed economic character, a change that wrought con-

4 Reid, "Manchester and Salford ILP”, passim; Carter, "The Independent Labour Party in Ashton-under-Lyne", passim.

5 Frederick Engels, The Condition of the Working Class in England (London. 1969), p. 266.

${ }_{6}$ Methodist Times, 18 July 1895. 
tradictory pressures on the working-class community. W. Cooke Taylor had noted in the 1840's that Manchester was "becoming daily more and more a commercial depot", ${ }^{7}$ ceasing to be a major manufacturing centre for cotton; from the middle of the century it was developing into the hub of a pulsating metropolitan conurbation that spread along the Irwell and Mersey valleys, creating a huge commercial zone. With the opening in 1894 of the Ship Canal the area's potential for growth seemed unlimited, and one observer dared to predict (not entirely inaccurately) that "eventually along its banks will be an unparalleled concentration of works transferred there on account of the economy of production". 8 But in the 1890's Manchester's development as a modern industrial base was only partially completed. The city represented in itself a case of uneven economic development: the old workshop trades of Ancoats and the Jewish tailoring shops of Strangeways still remained alongside the coalmines of Bradford and the even more modern engineering works developing in Salford. In fact Manchester experienced a proliferation of diverse occupations in the 1890 's and this brought about a fragmented labouring community; the monolithic occupational pattern of neighbouring towns like Oldham and Bolton - the result of dominant staple trades - was entirely absent. ${ }^{9}$ So too were the bases for the strong and extensive trade-union memberships characteristic of the cotton towns. Manchester trade unionism, despite the impetus of the "new union" boom in the early 'nineties, was never very strong before the First World War. Added to this was a further aspect of economic change that tended towards the fragmentation of the labouring class, namely the presence in the city of a number of immigrant communities: Germans, Lithuanians, Jews all gravitated from Europe into Manchester during the late nineteenth century to form their own self-contained districts. But most notable of all were the Irish - some 80,000 of them - packed into the densely populated streets of Hulme, in the South-Western part of the city, and in the district of St Michael's between the Oldham and Collyhurst roads. ${ }^{10}$ Here were some of the most overcrowded parts of an already overcrowded city. ${ }^{11}$

7 W. Cooke Taylor, Notes of a Tour in the Manufacturing Districts of Lancashire (London, 1842), p. 19.

8 Lord Egerton of Tatton, "The Manchester Ship Canal", in: The Nineteenth Century, XXXV (1894), p. 19.

9 See Appendix 1.

10 John Denvir, The Irish in Britain, from the earliest times to the fall and death of Parnell (London, 1892), p. 432: Manchester Guardian, 16 November 1885.

11 See John Tatham, Report on the Health of Greater Manchester, 1891-93 (Manchester, 1894), and T. R. Marr. Housing Conditions in Manchester and Salford (Manchester. 1904). 
But if growth fragmented the working class, it also had important effects upon the relationships between classes. Manchester's commercial functions created a significant population of middle-class businessmen and lower-middle-class black-coated workers, both spatially segregated from the proletarian communities. This process had started in the middle years of the century as the encroachment of factories, and warehouses had begun to threaten the fashionable bourgeois quarters of the city centre such as Upper Brook Street and Ardwick Green. From the mid century the wealthy Mancunians began to move out, initially into suburbs like Rusholme and Stretford, and later further south still in to select Cheshire villages, commuting to business by train. ${ }^{12}$ With the introduction of the telephone it even became possible to conduct one's affairs from St Anne's-on-Sea, forty miles away on the Fylde coast. ${ }^{13}$ This exodus of the Manchester business elite, perceptively chronicled by Katharine Chorley in her classic book Manchester Made Them, was complete by the end of the century: "the process spoilt the character of Manchester", says Mrs Chorley. "because if left her without her natural leaders."14 But the same concerns also created vast tracts of suburbia for the less opulent bourgeoisie: Withington, Burnage, Didsbury and Levenshulme were all new residential areas incorporated into Manchester's boundaries by the time of the First World War. ${ }^{15}$ And for every suburb of this type there were many more pockets of less wealthy but equally unproletarian life dotted about the two cities.

The separation of the classes in this way affected politics, since the placing of a physical and social barrier between the leadership of the two established parties and their potential working-class followers removed some of the bases for a shared political culture. Of the two the Liberals seem to have been more disadvantaged by this. Not only were their middle-class supporters all too frequently switching allegiance to the Conservatives, a feature noted by Katharine Chorley, ${ }^{16}$ but the Liberals were failing to attract popular support in sufficient quantities at election times. The decline of Liberalism as an electoral force was strikingly illustrated in the General Election of 1885 when, in defiance of the pre-poll optimism of the Liberal Manchester Guardian, ${ }^{17}$ the Tories swept the board

12 Katharine Chorley, Manchester Made Them (London, 1950), pp. 137-38.

13 In the case of Sir Charles Macara, see P. F. Clarke, Lancashire and the New Liberalism (Cambridge, 1971), p. 30.

14 Chorley, Manchester Made Them, p. 138.

15 Shena D. Simon, A Century of City Government: Manchester 1838-1938 (London, 1938), map facing p. 112.

16 Chorley. Manchester Made Them, pp. 234. 236.

17 See Manchester Guardian surveys of 14-25 November 1885. 
in the newly created working-class divisions of Manchester and Salford, thus prefiguring what was to be a near Tory hegemony in this area during the next fifteen or so years. ${ }^{18}$ Exactly why the Tories should have so bettered their rivals in the working-class districts is difficult to explain. Of course, given the limited size of the late-Victorian working-class electorate it is likely that even in predominantly proletarian constituencies the weight of middle-class votes would have been disproportionately heavy, so that Tory victories may have been less dependent upon the support of the labouring population than at first sight they appear. ${ }^{19}$ Nevertheless, the Tory Party probably enjoyed superior financial resources with which to mount electoral campaigns, ${ }^{20}$ whilst the Liberals were additionally penalised by their association with the Irish Question, hardly an electionwinning issue in the 'eighties and early 'nineties. Moreover Manchester, no less than other parts of Lancashire, presented the Tory Party with a congenial cultural environment in which to operate; the nationalist, or more precisely xenophobic, instincts induced among the native working class by the Irish-immigrant presence were an essential part of Tory ideology. ${ }^{21}$ The Irish community, its already separate ethnic identity doubly underlined by the energetic shepherding of the Salford Catholic diocese, ${ }^{22}$ was always likely to produce a conservative backlash among indigenous voters to the benefit of the Tories; this was especially so when such feelings were primed by an active and latitudinarian Established Church. ${ }^{23}$ The Tory position on the drink question also won the party support from working people, as it did in many other parts of the country. ${ }^{24}$

18 See Appendix II. Of the eleven constituencies in the immediate area of Manchester and Salford only Manchester North-West, containing the business vote, and Manchester South, and to a lesser extent Salford North and Stretford, were middle-class in character. 19 Cf. Paul Thompson. Socialists, Liberals and Labour: The Struggle for London, 1885-1914 (London, 1967), pp. 69-70.

${ }^{20}$ For the development of "New" Toryism in Manchester and its personnel see H. $\mathbf{J}$. Hanham, Elections and Party Management: Politics in the Time of Disraeli and Gladstone (London, 1959), pp. 314-22.

${ }^{21}$ For a fuller discussion of these issues see Clarke, Lancashire and the New Liberalism. op. cit., chs 2 and 3, and Jeffrey Hill, "Working Class Politics in Lancashire, 1885-1906: A Regional Study in the Origins of the Labour Party" (unpublished Ph.D. thesis, University of Keele, 1971). chs 5 and 6.

22 "There is perhaps no diocese in England better provided in respect to its parochial schools", recorded Herbert Vaughan on the work of his predecessor, Bishop Turner of Salford. Vaughan himself supervised major advances in school building and teacher training. See John Snead Cox, The Life of Cardinal Vaughan (2 vols; London, 1910), I, pp. $252,270,374,380,390$ and 414 .

${ }_{23}$ Thomas Hughes, James Fraser, Second Bishop of Manchester. A Memoir. 1818-1885 (London, 1888), pp. 246-57; Manchester Guardian, 23 September 1885.

24 See Clarke, Lancashire and the New Liberalism, pp. 34-36. 
In this atmosphere nonconformity, Liberalism's strongest point d'appui with the labouring classes in many other towns, possessed little relevance as a popular movement. As Benjamin Nightingale's extensive survey reveals, Manchester nonconformity tended to be concentrated in the suburbs ${ }^{25}$ with the poorer districts starved of chapel patronage, a fact recognised but not overcome by the Methodists. ${ }^{26}$ There was little evidence, apart from one or two cases where charismatic preachers drew good support, ${ }^{27}$ of the vital chapel society with strong roots in the working class that was so characteristic of, say, Bradford. Nevertheless the Liberal Party did retain one element of loyalty from a section of the working class and this came from the small, artisan-based organised labour movement. Among the craftsmen in the "respectable" trades - bookbinding, printing, engineering and tailoring, for example - there seems to have been little attraction to the Tory ethic. The Manchester and Salford Trades Council, established in 1866 and recruited almost exclusively from the skilled artisans until the later 'eighties, was a stronghold of Lib-Labism, the traditions being maintained by leaders like Peter Shorrocks of the Tailors, an executivecouncil member of the Manchester Liberal Union, and Henry Slatter of the Typographical Association, who in 1885 became Manchester's first JP to be drawn from the ranks of labour. By the mid 1880's these and other men were being succeeded by a younger generation of leaders schooled in the same traditions: Richard Watters, also of the Typographers, Matthew Arrandale, an engineer, and G. D. Kelley of the Lithograph Printers Society were the most prominent. ${ }^{28}$ Among organised workers of this type. for whom representation in Liberal Party counsels was a mark of status, Liberalism was an active creed capable of sustaining working men's clubs in a number of districts in the city. ${ }^{29}$

It was the political attachment of this section of the labour-force that gave the Liberal Party, despite its poor electoral performances, a crucial role in Manchester working-class politics after 1885. Although the Tories made some efforts to capture the loyalty of this group, they were certainly never able to speak as the authentic voice of the politically conscious and

25 Benjamin Nightingale, Lancashire Nonconformity (6 vols; Manchester, 1890-93), V, pp. $62 \mathrm{ff}$.

26 Methodist Monthly, February 1900.

27 For example S. F. Collier at Central Hall and the Wesleyan Mission in Oldham Street, and Mr Broxap at Gravel Lane. See George Jackson, Collier of Manchester: A Friend's Tribute (London, 1923), and Methodist Monthly, ibid.

28 See Leslie Bather, "A History of the Manchester and Salford Trades Council" (unpublished Ph.D. thesis, Manchester University, 1956), pp. 89ff.

29 Manchester Guardian, 17, 19.20 and 25 November 1885. Radical working men's clubs were active in Hulme, Newton, Pendleton and Bradford, among other places. 
motivated workers, and for this reason were never a factor of real significance in the politics of the organised working-class movement. The Liberals were, however, and it was their liaison with what was in many ways the vanguard of the working class that made them potential gainers from any extensions in the boundaries of the trade-union movement. This issue became especially important in the late 1880's and early 1890's with the launching of new industrial organisations among the labouring and semi-skilled sections of the local labour-force, which was accompanied by increased pressure for labour representation as a means of achieving an expanded programme of industrial and social reform. The question of the Liberal Party's ability, and willingness, to respond to this pressure assumed critical significance at this time, not merely for the party itself but for other political groupings hoping to capture working-class interest. For the socialists of the ILP in particular the presence of a Liberal party with close attachments to a section of the labour movement raised important questions about future developments.

The formation of the Manchester and Salford ILP in May 1892 came after almost three years of active working-class politics throughout the entire area of South-East Lancashire. Whatever the implications of this activity (and we shall see later where its main thrust lay), there can be little doubt that at the outset the ILP represented a markedly socialist political initiative. To say that the party was wholly concerned with implanting the ideals of socialism among the masses rather than seeking independent labour representation would, perhaps, be misleading. Both objectives were written into the party's Constitution, though the order of priority was not insignificant:

1 That the programme of the party be "The nationalisation of the land and other instruments of production";

2 That the party shall devote itself to securing the election of members to all representative bodies for the purpose of realising the programme of the party. ${ }^{30}$

Among the group of intellectuals who had been instrumental in launching the ILP, however, there was undoubtedly a very strong leaning towards socialist proselytising. John Trevor, for example, the former Unitarian minister at the Upper Book Street Chapel, established the Labour Church as a means of bringing socialism to the inner man: "the Emancipation of Labour", he proclaimed, "can only be realised so far as men learn both the

${ }^{30}$ Workman's Times, 28 May 1892. 
Economic and Moral Laws of God, and heartily endeavour to obey them." 31 Similar ideas about educating people into thinking differently about their condition before attempting a structural transformation of capitalist society could be found in the writings of journalists like Alex Thompson of the Clarion and the Cambridge graduate Fred Brocklehurst. They found their most powerful expression of all, however, in Robert Blatchford.

Blatchford exercised a profound influence over the early ILP in Manchester. He was its first president, from 1892 to 1893 , and at least until the Clarion ceased to be a purely Manchester-based paper the ILP was popularly known in the district as "Blatchford's Party". ${ }^{32}$ His socialism was clear, simple and emotional. "The policy of The Clarion", he declared in his first issue, "is a policy of humanity", ${ }^{33}$ and, casting himself as its "recruiting sergeant", he sought to make it the ideology of a mass movement. His indictment of industrial capitalism, Merrie England, sold three quarters of a million copies within a year of its publication in 1893, and helped to spawn a whole clutch of Clarion clubs for cycling, singing, scouting, rambling and other pursuits in which was nurtured a distinctive socialist culture. As an instrument in opinion forming Blatchford believed infinitely more in the power of the press than of Parliament: "Parliament follows public opinion", he argued, "it does not lead", 34 and this meant that the Clarion adopted a low-key approach to the electoral ambitions of the ILP. It was envisaged that the party "would be more than a mere electoral club, but would educate and expose injustice". ${ }^{35}$ As far as electioneering was pursued, moreover, Blatchford urged an uncompromising stance, realising that in Manchester a party aiming for a genuinely working-class image would need to challenge not only the Liberals, as in other areas, but also the Tories: "both parties are our enemies and our object is to defeat both." 36 This position was enshrined in the celebrated Fourth Clause of the party's Constitution, which prevented ILP members from voting at elections for the candidates of any other political party.

Influenced by such a passionately socialist propagandist, then, it is perhaps not surprising that the Manchester ILP began its political life with a strategy that often brought the party in to conflict with other ILP groups in the North. But it was not only Blatchford's hand that guided the

31 Labour Prophet, February 1892.

32 See article by Alex Thompson in Manchester Guardian, 1 January 1944.

33 Clarion. 12 December 1891.

34 Ibid., 11 February 1893.

35 Ibid., 28 May 1892.

36 Ibid., 11 February 1893. 
Manchester movement. One of the most active sources of support for the creation of an ILP in this area, and one which historians have tended to overlook, was the Social Democratic Federation. The SDF had been established in Manchester since the mid 1880's and by the time of the ILP's formation had served a testing apprenticeship in a hostile environment. It had always been a small party (possibly fifty members were attached to its main branch in Salford) whose energies had been dissipated in early days by the adoption of a too revolutionary stance. But some success was experienced by Social Democrats in 1886 and 1887 through leading a series of campaigns on the problem of unemployment, a real issue among the working class in the heart of Salford. Under the direction of John Hunter-Watts the SDF organised hunger marches, open-air demonstrations, processions and petitions to the Salford City Council, demanding a public-works programme to relieve the unemployment in the area. ${ }^{37}$ These campaigns, centred on the populous and deprived districts of Ordsall and the Eccles New Road, created a fresh dimension in street politics and provided propaganda techniques that were to be incorporated into later ILP work. On the whole the Social Democrats had eschewed formal politics, believing electioneering to be the first step towards compromise with the established system. This view was especially strong in the speeches and writings of the SDF's national leader, H. M. Hyndman, whose influence over provincial branches at this time was profound. "Let us only recognise", Hyndman asserted, "that political action is [...] more in the interests of the possessing classes - as likely to save them from attempts at violent revenge - than of the proletariat." ${ }^{38}$ The same attitude characterised the SDF's relationship with trade unions, which were regarded as sectional institutions incapable of reflecting the aspirations of the whole working class.

In the course of time, however, local branches of the SDF began to establish their own autonomy, and this enabled them to adopt a less intransigent policy towards other manifestations of popular action. By the end of the 1880's, for example, the Salford SDF was directing its attention to the question of "new unionism" among the unskilled labourers of the area and beginning to offer practical assistance in strikes. Bill Horrocks, W. K. Hall and George Tabbron, all leading Social Democrats from Salford, were involved in the struggle of the Gasworks labourers to win better conditions from the local Corporation, ${ }^{39}$ whilst Leonard Hall, a veteran of both the SDF and the Socialist League (and later President of the ILP), set

${ }_{37}$ For example, Justice, 19 January, 12 February and 10 December 1887.

38 Ibid., 1 January.

39 Ibid., 10 November 1888, 6 April and 14 September 1889. 
up the Navvies' Guide as a recruiting news-sheet for labourers, and later formed the Lancashire and Adjacent Counties Labour Amalgamation. ${ }^{40}$ By this time the SDF had shed much of its earlier sectarian outlook and was willing to co-operate with other labour groups. In the spring of 1892, for example, W. K. Hall stood as Parliamentary candidate in the South Salford constituency, adopting as a means of capturing working-class support a programme of radical measures that were little different from those of his Liberal opponent. ${ }^{41}$ The ultimate example of the SDF's readiness to liaise was provided in May of the same year when, at the inaugural conference of the ILP in the St James Hall, five Social Democrats were prominent on the platform. ${ }^{42}$

The SDF's involvement in the new party brought a Marxist legacy, which fused with the less precise but no less vigorous socialism of the Blatchfordites - derived, according to Blatchford himself, from Hyndman, William Morris and (an anonymous demotic influence) "a poor devil of a workman". ${ }^{43}$ For the next decade or so the SDF was to remain an essential element of the ILP with co-operation between the two bodies a marked feature of propaganda. At times their organisations became so close as to make any distinctions between them almost imperceptible, and it was no doubt this liaison which inspired and strengthened the tendency towards the idea of socialist unity in the Manchester ILP. Blatchford was a stubborn advocate of this at both local and national levels; it accounted partly for his quarrels with Keir Hardie and for the tension that existed between Blatchford and other Manchester members like Brocklehurst and Leonard Hall, who were on the National Administrative Council of the party. But the sucess of the Clarion movement ensured that Blatchford's influence always had a residual place in the Manchester ILP even after Blatchford resigned his presidency in 1893 and took the Clarion off to Fleet Street. Consequently, as Reid has shown, there was a fairly permanent socialist polarity in the party, which pulled against the development of a Bradford-style labourism in Manchester. ${ }^{44}$

But how representative of local working-class opinion was the ILP? It was formed at a time when the general climate of labour thinking was being stimulated by the trade-union revival, which brought in its wake a far

40 Labour Prophet, February 1894.

41 Salford Chronicle, 12 March and 9 April 1892. Hall propounded Home Rule for Ireland, old-age pensions and payment of MPS as his main policies.

42 Workman's Times, 28 May 1892. They were Leonard Hall, W. K. Hall, Tom Purves, Alf Settle and G. Evans.

${ }^{43}$ Robert Blatchford to G. B. Shaw, 18 August 1892, Shaw Correspondence, Series I,

British Library, Add. Mss 50512.

${ }^{44}$ Reid, "Manchester and Salford ILP", p. 26. 
greater awareness than before of the virtues of collective action through both industrial and political methods. Manchester saw a cascade of new industrial formations in the early 'nineties encompassing a variety of previously unorganised trades: navvies, tramway workers, carters and lurrymen, paviours, hairdressers, quarrymen, cab-drivers, porters, watermen and many others all came under the influence of industrial organisation to a greater or lesser extent. But the impact of these developments was often less than at the time was anticipated. Initially many unions, taking their cue from the success of the Gasworkers in the summer of 1889 when these were organised into a branch of Will Thorne's national union and secured eight-hour shifts from the Corporation, took up their specific grievances and met with early triumphs. John Kelly's Carters and Lurrymen of Salford, for instance, quickly managed to improve the rates of pay for coal carters ${ }^{45}$ and similar early successes came the way of the Shop Assistants, led by the socialist William Jackson, and the Tramway Employees organised by his namesake G. T. Jackson. But setbacks were also common. At the end of 1889 , only six months after their triumphal emergence, the celebrated Gasworkers suffered a disastrous defeat in attempting to enforce the principle of "every man with a ticket" upon an unwilling Gas Committee. Employer resistance of this kind, together with poor management and inter-union rivalry, accounted for many failures especially with the return of bad trade by 1892 . The numerical impact of the new unions in Manchester and Salford is difficult to estimate, therefore; national unions like the Dock Labourers and the Tramway Employees (who absorbed the Carters and Lurrymen of Salford) recruited well, whilst of the specifically Manchester-based unions the Quay and Railway Porters and the British Labour Amalgamation (a reorganisation by the socialist Tom Fox of Leonard Hall's original Labour Amalgamation) probably exercised the most influence locally during the 1890's. ${ }^{46}$ Of the smaller bodies, whose memberships rarely rose above a few hundred (the Women Workers' Federation, the Jewish Tailors and the Shirt and Jacket Cutters are good examples), the majority made their contribution to the labour movement through the Trades Council; its increased membership at this time in fact reflected the growing numbers of new unionists - from 1892 its membership reached some 25,000 with about 100 affiliated societies and this figure was generally maintained during the

45 Workman's Times, 11 September 1891.

46 The principal new unions in the Manchester area by 1900 were: Dock Labourers (total national membership 14,493), Labour Amalgamation (1,608), Tramway Employees (national, 7,536), Quay and Railway Porters $(3,400)$. Board of Trade, Labour Department, Report on Trades Unions in 1899 [Cd 422]. 
remainder of the 1890 's. ${ }^{47}$ So, whilst we should be careful of overestimating their strength, it seems that the new unionists achieved an extension of the organised working class of some significance.

As far as the political implications of this development are concerned, however, there is little evidence to suggest that new unionism brought about a radical change in the direction of working-class political allegiances. The membership was undoubtedly composed of "outsiders" who had not shared in the creation of Lib-Labism, but, on the other hand, they were not necessarily automatic supporters of socialism. Where links between the new unions and the ILP can clearly be established is among the leadership: a whole cadre of new-union organisers - among whom were such people as Leonard Hall, James Heaviside, John Harker and Tom Fox - achieved positions of prominence in the ILP during the 1890's; but whether their views and influence extended down to their memberships is a different matter. The essential point perhaps is that the radicalism of these men had not been formed as a result of their specific experiences as new unionists so much as it was a consequence of general social pressures. A good example of this type of leader was J. R. Clynes, the later Labour Minister who, although based in nearby Oldham in his early career, nevertheless had many contacts with Manchester, for which he became an MP in $1906 .{ }^{48}$ Clynes was the son of an Irish labourer and was brought up in Oldham, where he attended a local Catholic School. He left at the age of ten with some unhappy memories and went to work in a cotton mill as a "little piecer", soon rebelling against the harsh discipline and low wages of his trade. As an adolescent he was writing letters to local newspapers to publicise the piecers' conditions and in the mid 'eighties, when he was no more than sixteen or seventeen, he organised a trade union for his fellow workers in an attempt to force better treatment from the spinners (in Clynes's own words "it did not last very long"). His political initiation was through the Irish National League, and philosophically he cultivated an eclectic code through reading Ruskin, Carlyle, Mill and Emerson. Shortly after the Manchester gas strike of 1889 Clynes was enlisted by Will Thorne to act as an organiser for his union in the North-West and thus began a long association with the labour movement. Soon after his transfer from mill to trade union he joined the ILP. Looking back, Clynes was able to connect his union and socialist activities quite naturally.

${ }_{47}$ Manchester and Salford Trades Council, Annual Reports, 1892, 1895, 1897-99, Manchester Public Library.

48 On Clynes see J. R. Clynes, Memoirs (2 vols; London, 1937); Edward George. From Mill Boy to Minister (London, n.d.), chs V-VIII; Will Thorne, My Life's Battles (London, n.d.), pp. 114-16. 
It soon became obvious that Unions acting only in the affairs of the workshop could never attain their objects satisfactorily. These objects went further than mere isolated protests against unfair conditions in specified trades; they aimed at an eventual state when the whole of Britain should accept as a working axiom the Biblical assurance that "A labourer is worthy of his hire". We wanted the men who made the profits to share the profits to a larger degree. ${ }^{49}$

Clynes was typical of the younger rebels whose aggressive awareness of social and economic injustice caused them to seek a new means of emancipating the working class, and their search took them in to industrial and political channels. But the new-union thrust was not invariably in this direction. Some unions, Kelly's Carters and Lurrymen was a good example, never took to socialism, whilst others assumed a political stance for the same reasons that accounted for a change in the policy of craft unions at this time. Indeed, the artisans probably exercised an important influence over new-union growth in the early 1890's. G. D. Kelley had actively sought, as secretary of the Trades Council, to recruit new members, and frequently had taken the lead himself in offering advice and assistance to groups, like the Brushmakers or the Cloth Hat and Cap Makers, who were endeavouring to organise for the first time.$^{50}$ Kelley's policy was not wholly altruistic, moreover, for by extending the bases of the local labour movement in this way he was also helping to fortify the position of the craftsmen themselves. By the late 1880's most craft trades were being threatened nationally by advancing technology combined with foreign competition, and steps were being taken by the unions in the engineering, boot and shoe, printing and many other trades to ward off unemployment and the undermining of wage levels. In this atmosphere Manchester opinion could hardly have been unaffected by an alarming manifestation of the dangers facing skilled men in the form of a lengthy and violent strike over wage rates in the nearby town of Bolton in 1887. Here the engineering trade had been convulsed by a six-month stoppage during which the employers, acting on a co-ordinated, national basis against the local efforts of the workers, had used systematic mass importations of blackleg labour backed by large formations of police and military to break the engineers' resistance. ${ }^{51}$ In the light of this it is not surprising that the Trades Council leadership in Manchester and Salford sought to strengthen the local working-class movement by union building and, at the same time, to

49 Clynes, Memoirs, I, p. 69

50 Workman's Times, 5 September 1890 and 17 March 1894.

51 Bolton Weekly Guardian, 2 and 9 July 1887; James Glegg, Annals of Bolton (Bolton, 1888), p. 227. 
fashion other weapons of self-defence, notably political ones. During 1890 the Trades Council formulated a programme of demands for legislative action on Fair Contracts and Eight Hours, and stepped up pressure on the Liberal Party for labour representation. ${ }^{52}$ By methods such as these the traditional craft leadership of the Trades Council not only maintained its control over the local labour movement, but managed to avoid any serious confrontations between the old and new unions. Harmony on the whole characterised inter-trade union relations in Manchester, in contrast to the internecine quarrelling often evident in other towns.

A further key influence in the formation of a labour, rather than socialist, consciousness was that exercised by the Workman's Times and its editor, Joseph Burgess. Burgess, a local man born at Failsworth in 1853, was a campaigning journalist who had long been associated with independent newspapers. When his own Oldham Operative failed after a short spell in the mid 'eighties, he had joined the staff of the influential trade-union journal The Cotton Factory Times and thus sharpened his knowledge of industrial affairs. ${ }^{53}$ From 1890 to 1894 he edited the Workman's Times, assisted by James Bartley, who ran the Northern edition when Burgess himself moved to Fleet Street in 1891 to extend his operations. The paper became a vademecum for trade unionists in the North and Midlands, providing a wealth of information and practical help as well as moral support. In Burgess's hands the Workman's Times endeavoured to canalise industrial struggles into political confrontation with the established parties, thus pointing the way towards independent politics. This was the hallmark of Burgess's message: he called for the workers to fashion their own weapon which would defend their interests in a way the parties of the bourgeoisie never could.

... it would not, we know, be a difficult matter to show that the Liberal Party had done a good deal for the working man. But neither would it be hard to prove that the Conservative Party had also done a good deal for him. That, however, is not the question. It is not what either party has done but what they have not done that we are most concerned for ${ }^{54}$

For this reason Burgess opposed organisations like the national Labour Electoral Association, which operated under the auspices of the Liberal Party. It was he, appropriately, who first began to use the term "independent labour party" to express his principle - "it is to assist in the

52 Workman's Times, 26 September and 24 October 1890.

53 Joseph Burgess, A Potential Poet? His Autobiography and Verse (Ilford, 1927), passim.

54 Workman's Times, 3 April 1891. 
creation of such a party that we dedicate our best efforts", he told his readers. ${ }^{55}$ Though a socialist, Burgess exuded little of the passion associated with Blatch ford and the Clarion. In later years he became a keen supporter of Keir Hardie, but in the early 1890's his main interests were in labour representation. Of his scheme for an independent party he wrote:

Its main object is the formation of a healthy public opinion in connection with working-class questions. This public opinion can be created in no way so speedily as by bringing Independent Labour candidates into the political arena, and running them on really independent lines. ${ }^{56}$

This "healthy public opinion" involved for Burgess, in contrast to Blatchford, no attempt to formulate a serious anti-capitalist ideology. Although he frequently attacked the Liberals and their labour allies like Matthew Arrandale ("he has 'hob-nobbed' with party politicians", ${ }^{57}$ complained Burgess on one occasion), his philosophy scarcely extended beyond the ideological bases of popular radicalism.

The views of Burgess and the Workman's Times, however, seemed to reflect well the general aims of the labour movement at this time in Manchester. With trade unionists both old and new turning more readily to the notion of legislative solutions to industrial problems, the issue of labour representation was very much alive. The Trades Council had become affiliated to the national Labour Electoral Association with G. D. Kelley taking a leading part in pressing the Liberals for more consideration to labour. Locally pressure was building up from trade unionists on the Manchester Liberal Union for more working men candidates in municipal elections. By 1891 the Liberal Party's traditional role as the champion of organised labour was under close examination.

\section{III}

As for the Liberal leadership, it was slow to respond to the challenge from below. The party had fallen under the dominance of a social elite. The party machinery, re-fashioned in 1885 on a divisional basis to correspond to the new electoral system, had quickly become reliant upon the middleclass suburban associations. They provided the real source of party finances, channelling their money through the central treasury to maintain the impecunious organisations in the working-class districts. But by thus paying the piper the wealthy element was able to call the tune on policy,

55 Ibid.

56 Ibid., 16 January 1892

57 Ibid., 27 March 1891, 
and it generally favoured Constitutional issues such as Home Rule as against the industrial reforms or labour representation which interested organised Labour. ${ }^{58}$ When the Trades Council began to press for what amounted to a louder voice in Liberal Party affairs, the Manchester Liberal Union was largely unsympathetic. In 1890 a ground swell of rank-and-file discontent was evident in the Trades Council and it was only a matter of time before it erupted. This happened when J. Jenkins of the Bakers' Union, a self-confessed "rabid radical", led a move to force Kelley, Arrandale and Watters into a more determined position on labour representation; Jenkins's well-supported resolution contained a thinly veiled threat to the Liberal Party "that it be an instruction to the Executive Committee [of the Trades Council] to consider and report to the Council the best means to adopt to secure the representation of labour on the city council". 59 In the following year Kelley was in fact elected to the Manchester City Council as a Lib-Lab, although at the same time the Manchester School Board Liberal Candidates Committee rejected all but one of the names submitted to it for the School Board elections by the Trades Council. This snub was rendered more injurious when the Council's written request for further talks about the proposed candidatures was ignored. After waiting for almost two months during the summer of 1891 for a Liberal response, the Trades Council finally informed the MLU that there would be no further dealings between the two bodies over labour candidates. Though the Liberals soon afterwards relented and invited the Trades Council to submit nominations for a Free Board School Party, the Council stood firm on its previous decision. ${ }^{60}$

It was in this context that the Salford Labour Electoral Association was formed at a series of meetings held during July and August in the Trafford Hotel. The Association, or "Labour Union" as it was more commonly referred to, derived much of its inspiration from the Bradford body set up earlier in the year and, indeed, James Bartley of the Workman's Times, a pioneer of the Bradford ILP, attended the inaugural meetings in Salford to address the delegates on events in the West Riding. In the words of John Kelly, secretary of the Carters' and Lurrymen's new union, the Salford Labour Union "would embrace all shades of political opinion", 61 and for a short time it certainly proved capable of drawing together a diverse group of people all hostile in varying degrees to the established political parties.

58 Manchester Liberal Union. Minute Book of Liberal 1200, 29 April and 27 July 1886. Offices of Manchester Liberal Federation.

59 Workman's Times, 24 October 1890.

${ }_{60}$ For details ibid., 28 August 1891.

61 Ibid., 7 August. 
In addition to Kelly, a new-unionist radical grown disillusioned with both the Liberals and the Tories (neither, he asserted, "care three ha'port of common gin" for the working $\operatorname{man}^{62}$ ), the Labour Union was supported by all shades of opinion: Richard Watters and George Rogerson, both members of long-established craft unions and leaders of the Trades Council, attended its meetings alongside, for example, Alf Settle, the Marxist copper-plate engraver who had worked with the SDF in Salford, and his socialist friends George Tabbron of the Brassfounders and G. T. Jackson of the Tramway Employees. Prominent also were James Heaviside and J. Jenkins, whose resolution of 1890 had helped to precipate the organisation. ${ }^{63}$ As such, the Labour Union was the first real manifestation of independent labour politics in the Manchester area. But its experiences were very different from those of its counterpart in Bradford, where the Labour Union provided the foundations for a united labour alliance soon to be transformed into the ILP.

In Manchester it proved impossible to sustain the unity of 1891. Socialism became the major stumbling block. Early disagreement over the nature of the Union prefigured this, some people looking for a party that would serve as an organisational vehicle for independent labour representation whilst others, more ambitiously, sought to build a movement with individual membership and a strong ideological commitment. It was Alf Settle who brought the entire issue to the point of confrontation in a meeting during August by declaring that "if he joined the association he should endeavour to make it subservient to his Socialistic instincts"; as a further challenge he added that he "would try to get it worked along the lines he advocated: but if he found it went contrary to his opinions he would not support it". ${ }^{44}$ Settle's intervention in this manner caused conflict within the Union to rage divisively, nowhere more so than in the municipal elections of that year, in which Settle himself figured. There were two labour candidates in Salford sponsored by the Union: George Rogerson in Regent Ward and Settle at Ordsall, where he had polled well for the SDF in 1890. Rogerson's chances were thin and indeed he was defeated, but Settle might well have been successful had it not been for the intervention of John Kelly in the contest, sponsored by his union as a candidate to fight specifically against the influence of socialism. Kelly regarded Settle, who was not a trade unionist, as an opponent of Liberalism and therefore opposed him in the guise of a truer representative of labour. As a result the

62 Ibid., 18 September.

63 Ibid., 7 August.

64 Ibid., 21 August. 
working-class vote was split and the Tory candidate, Rudman, easily topped the poll. ${ }^{65}$ Further illustrations of this endemic conflict were provided during the winter, when quarrels arose over the selection of another socialist, W. K. Hall, as a Labour Parliamentary candidate for South Salford: the choice upset a good many non-socialists, and this no doubt contributed to Hall's poor performance in the General Election of $1892 .{ }^{66}$ By the spring of that year the Salford Labour Union appears to have become practically defunct, the labour unity it had momentarily enshrined shattered by ideological dispute.

There is, therefore, considerable value in the notion of two traditions, a "socialist" and a "labourist", in Manchester working-class politics at this time, the gap between them being probably wider than that in Bradford between the ILP'ers and the Lib-Lab old guard. Socialism in 1891-92 clearly had little chance of becoming the complete expression of Manchester working-class opinion: for one thing the ideology of the SDF and the Clarion was probably more adventurous than the reformist perspectives of the Bradford ILP, whilst for another there was less of a sense of class confrontation in Manchester. The MLU's attitude was certainly not encouraging for labour but Manchester Liberals appeared to exhibit little of the outright aggression towards the idea of independent labour representation evinced by their Bradford counterparts. Moreover, the absence of an issue equivalent in magnitude to the Manningham Mills strike meant that questions of an industrial-relations nature rarely came to be generalised into issues of class and power, which might have lent credence to socialist thinking. For these reasons, then, the formation of the Manchester and Salford ILP in 1892, far from heralding the arrival of an angry and coherent mass labour movement, represented little more than a union of socialists. Its relatively humble origins were perhaps best symbolised in the description given by one of its early adherents, Sylvia Pankhurst, of the party's meeting place: "a poorly lit, evil-smelling room over a stable, in a side-street off Oxford Road". 67

With working-class politics in retreat at the time of its formation the ILP's future was problematical. As befits a new group of political militants, the party's own estimation of its prospects were optimistic: "it will grow", predicted Blatchford, "it will spread out its roots over the country." 68 The early proliferation of branches throughout the North in 1892 and 1893 appeared to vindicate this view as the ILP soon achieved parity with the

65 Ibid., 7 November.

66 Ibid., 12 March 1892. Hall received 553 votes, less than $8 \%$ of the poll.

67 E. Sylvia Pankhurst, The Suffragette Movement (London. 1931). p. 128.

68 Clarion. 28 May 1892. 
SDF and probably surpassed it in most places. But this achievement was of marginal value when set against the fact that, despite its often considerable propagandist efforts, the ILP neither had much of an electoral impact nor secured a particularly high membership. ${ }^{69}$ It could certainly not claim to be a mass party. The realisation of this fact caused most ILP groups in the North to seek an alliance with trade unions sooner or later: in Manchester the pressures for "labourism" were especially strong and can be seen from a relatively early stage in the party's development. One of the most compelling reasons for this lay in the threat of a Liberal revival amongst the organised working class in the mid 'nineties.

IV

Following the repercussions of the MLU's lukewarm response to labour demands in 1891 , the party began to reconsider its relationship with the Trades Council. Without a more positive initiative the prospects for a continuation of the traditional Lib-Lab alliance were undoubtedly very dim, and by 1893 a radical element had come to prominence in local Liberal circles advocating an active programme to recoup labour support. The appearance of the ILP in 1892 and its early ambitious attempts to become an electoral force - twelve candidates were put forward by the socialists in 1893, though none was actually elected - enabled this radical element to goad the Liberal Union into action. It is clear from reports in the districts that Liberals regarded the ILP as a real threat at local and parliamentary levels, and it was to consider ways and means of withstanding such a challenge that the MLU convened a special meeting in November $1893 .{ }^{70}$ But it soon became apparent at this meeting that even the radical group of Liberals were divided over the most suitable methods to employ. Broadly speaking two views emerged. On the one hand a faction led by Alderman Edwin Guthrie and his friend C. P. Scott, editor of the Manchester Guardian, favoured a policy of increased labour representation as a means of courting the non-socialist elements of the labour movement; their feeling was that such a manoeuvre would serve to outflank the ILP and arrest any drift towards socialism. But, on the other hand, there was

69 There were 26 branches of the ILP reported in Lancashire in January 1894, 45 the following year. Workman's Times, 13 January 1894; Labour Annual 1895, pp. 103ff. In February 1894 the SDF reported 27 branches in Lancashire, Justice. 19 May 1894. The ILP Directory and Branch Returns for 1897 listed membership of branches in the Manchester district at 693. In 1898 the financial membership of the Manchester and Salford ILP was estimated at 268, by March 1899 at 401, Manchester, December 1900.

${ }^{70}$ Manchester Liberal Union, General Committee Minutes, 17 November 1893, letter of 16 November. 
strong feeling in the MLU about conceding power and influence to the working class, and it was in order to appease these sentiments that $\mathrm{J}$. Harrop proposed a counter-measure: to steal the ILP's clothes by coming out with a strong measure of social reform. As Harrop put it, the Liberals should "adopt so much of the Labour Party's programme as is possible" and by these means avoid the humiliating experience of going "cap in hand" to organised labour. ${ }^{71}$ What in all probability decided the issue was the fact that the Guthrie-Scott group overplayed their hand; given the traditional social configurations of Manchester Liberalism the prospect of a radical devolution of power to the organised working class was difficult to accept, even when proposed in such diplomatic terms as T. G. Ashton's, "that the Manchester Liberal Union recommends each division of Manchester to carefully consider the advisability of recommending certain wards in their division to adopt representatives of labour as candidates in the next municipal vacancies". ${ }^{2}$ In the face of this members preferred to embrace Harrop's scheme, and the Committee eventually agreed to frame "an advanced municipal programme for Manchester" in consultation with Liberal City Councillors. In the following spring a Programme SubCommittee reported with a provisional list of some twenty reforms, included in which was a rather obscure and vague reference to "more labour representatives". In July 1894 the full committee of the MLU adopted this scheme as the Progressive Municipal Programme. ${ }^{73}$

As P. F. Clarke has shown, Guthrie and Scott did not rest content with this decision, but continued to pursue their objectives by exploiting the reference to labour representation. ${ }^{74}$ Guthrie, in fact, took up the issue with both the Prime Minister, Lord Rosebery, and with leaders of the National Liberal Federation, arguing that it was imperative to outmanoeuvre socialism by "adopting a considerably increased number of working men" in Manchester ${ }^{75}$ Contact was also made with three influential local union leaders, Francis Chandler, Matt Arrandale and G. D. Kelley, all of whom appeared favourably inclined to the new Liberal attitude, and obligingly offered recommendations for labour candidates in City Council and School Board elections. ${ }^{76}$ At this point, therefore, it seemed likely that Guthrie's initiative might have effect and that Manchester Liberalism

71 Ibid.

72 Ibid.

${ }^{73}$ Manchester Liberal Union, Programme Sub-Committee Minutes. 2 March. 28 May and 13 June 1894; General Committee Minutes, 5 July.

74 Clarke. Lancashire and the New Liberalism. pp. 164-65.

75 Manchester Liberal Union, General Committee Minutes, 26 July 1894.

${ }^{76}$ Ibid., 1 and 14 August. 
might indeed forge an alliance that would re-unite the working class with the bourgeoisie. But a combination of factors conspired against such an eventuality. For one thing no encouragement was forthcoming from the party's national leadership; Rosebery failed to take a lead and the National Liberal Federation eventually pronounced that such a scheme involved too many difficulties, "both financial and of other kinds". ${ }^{77}$ Furthermore the ILP's electoral assault, so vividly imagined in 1893, was seen two years later to have been only a turnip ghost. By this time the ILP's municipal successes in Manchester were limited to the return of J. E. Sutton as City Councillor for Bradford Ward, whilst in the General Election ILP candidatures in the Manchester area had been a disastrous failure. ${ }^{78}$ With its earlier fears shown to have been unfounded as far as ILP socialism was concerned, therefore, the MLU felt able to forget about labour representation and rely on the Progressive Programme to win working-class votes. The practical extent of Guthrie and Scott's proposals was limited to the election of Matt Arrandale to the City Council, where he joined Kelley in 1895. Discussion on the subject of labour candidates continued in Liberal circles in the later 'nineties, but without producing any significant achievements. Opposition to campaigns for labour representation, as occurred in 1899 at Harpurhey and St Marks for example, ${ }^{79}$ still tended to outweigh efforts to co-operate with them, and for this reason advocates of labour representation were driven into the arms of the ILP.

What might have resulted from a wholehearted pursuit of the GuthrieScott plans is hard to judge. It is, however, difficult to believe that Liberalism was at this time facing an objectively hopeless situation or that had the Liberals revealed more determination to throw off their social prejudices the advocates of labour representation could not have been contained within the established party framework. But the failure to act more positively certainly had some obvious effects. By the end of the decade the Trades Council was engaging in increasing electoral activity with the ILP, whose reformist municipal politics offered everything included in the Liberal programme and more besides. Moreover, in many of the poorer districts of the city the absence of active working-class participation in

77 Ibid., report of sub-committee meeting. 19 December.

78 The ILP put up two candidates in the immediate area of Manchester and Salford. R. M. Pankhurst, an erstwhile Liberal, received 4.261 votes at Gorton, but had no Liberal opponent; James Johnston at Manchester North-East received only 546 votes. whilst in nearby Ashton-under-Lyne and Hyde ILP candidates similarly polled badly. less than 500 votes in both cases.

79 Manchester, July and October 1899; Manchester Liberal Union, General Committee Minutes, 17 June and 6 October 1898. 
Liberal Party organisation caused morale to evaporate almost completely. When Herbert Gladstone, as Liberal Chief Whip, intervened in Manchester affairs in 1902, he found Liberal organisation badly in need of re-invigoration, and it was largely through his inspiration that the MLU was reformed in 1903 as the Manchester Liberal Federation. This new structure overcame some of the old autonomy of the Divisional Associations, which in the past had been a conservative influence in the party, and enabled Liberals to adopt a more realistic approach to labour. ${ }^{80}$ But it was ironic that the establishment of the MLF coincided with the formation of a Labour Representation Committee for Manchester and Salford based on the local trade-union and socialist movements. Never could the aphorism "too little, too late" have been more appropriately applied to Liberal endeavours.

\section{$\mathrm{V}$}

Liberalism's failure arose from a fundamental misreading of the local political situation. In short, the MLU overestimated the challenge of the ILP, and by so doing overlooked the legitimate and on the whole nonsocialist claims of organised labour. For its part the ILP was quick to respond to this, and there was considerable dexterity in the way ILP organisers managed to align the party's development with that of the labour movement in general and the Trades Council in particular.

In doing this, however, they had to overcome the strong tendencies towards socialist, as against labour, politics, which were best represented by Blatchford. Blatchford's resignation as president of the Manchester ILP in 1893 was an important step in this development, for it marked his gradual removal as the central figure in the local party. Initially his resignation seems to have been brought about by an aversion on his part to the notion of "leadership", his dislike of which became more intense in 1894 with the election of Keir Hardie as president of the national movement. ${ }^{81}$ Additionally, however, Blatchford had touted the cause of socialist unity during 1893 and 1894 , and this not only produced conflict with other local groups, but unsettled relations in Manchester. Burgess opposed Blatchford on the issue from the beginning, accusing him of "scuttling the ship", 82 and Leonard Hall and Fred Brocklehurst became increasingly

80 Details in Herbert Gladstone Papers, British Library, Add. Mss 46105, 46106 and 46454.

81 In 1893 he wrote: "We want no leaders, and should be ill-advised to tolerate any", a remark ostensibly prompted by his distaste for C. S. Parnell, the Irish Nationalist leader. but implicitly referring to Keir Hardie. Clarion, 11 February 1893.

82 Ibid., 11 August 1894. 
sceptical of the policy after their election onto the ILP's National Administrative Council. Disagreements over policy grew during 1894 with Blatchford fanning the flames by making personal attacks on Leonard Hall, who had succeeded him as president in Manchester. Hall eventually resigned the post himself, soon after renouncing the Fourth Clause and dropping his intended candidature for the Parliamentary seat in NorthEast Manchester. ${ }^{83}$ Personal rivalries of this kind did not help to prepare the party for the General Election of 1895 , in which two ILP candidates were put forward in the Manchester area; it is not surprising that they fared poorly.

But the removal of Blatchford and other members of the original intellectual group from influential positions in the party meant that by the mid 1890's a body of less well-known leaders was coming to exercise more control over party policy. Many of them were trade unionists: Sutton of the Miners, Harker of the Shirt and Jacket Cutters, Nuttall of the Block Roller and Stamp Cutters, Fox of the Labour Amalgamation, and, later, Doyle of the Concreters and Purcell of the French Polishers. Between them they were able to form links with the Trades Council. What is interesting in this is the way the ILP allowed its policies to dovetail with those already taken up by the Trades Council well before any strong socialist representation became evident in its leadership. In the early 1890's the Trades Council, still firmly in the grip of its artisan leadership, had launched progressive campaigns for an eight-hour day, the nationalisation of land and railways, and public-works schemes for the relief of unemployment. Allied to these were assertive claims for labour representation at municipal and national levels. ${ }^{84}$ It is in the light of this that we should view the ILP's twelve independent candidates in the municipal elections of 1893 - quite apart from the total failure of the campaign in electoral terms a valuable demonstration of the party's independent labour stance -, and the equally important series of demonstrations, hunger marches and soup kitchens organised by the party in the same year on behalf of the unemployed. ${ }^{85}$ Moreover, during the mining lock-out of 1893 R. M. Pankhurst, a notable local radical who had recently been converted to the ILP, toured the pit districts of Bradford and Clayton in the Eastern part of the city lecturing on the principles of nationalisation in the mines, ${ }^{86}$ a socialist measure but one likely to appeal to miners with a strong sense of grievance about their

\footnotetext{
83 For details see ibid., 25 August, 24 November, 1 and 8 December; 29 June 1895.

${ }^{84}$ Manchester and Salford Trades Council, Annual Reports, 1892 and 1895.

85 Manchester Guardian, 2 November 1893; Pankhurst, The Suffragette Movement, op. cit., pp. 95, 129-30.

86 Ibid., p. 125
} 
employers' conduct. Shortly afterwards Joseph Burgess and three local ILP activists, Bilcliffe, Harker and Heaviside, took the issue further by setting up the Colliery Workman's Times as a weekly journal to promote "the nationalisation of the mines by and through the independent representation of labour in Parliament", 87 thus neatly combining the socialist and independent-labour aspects of the ILP's constitution.

The efforts were in fact a great success. Not only was an ILP branch formed among the colliers in Bradford, but their local secretary, J. E. Sutton, was converted and thus began a distinguished career with the party, on whose behalf he was elected to the City Council in the following year. ${ }^{88}$ Through such activities and contacts the ILP was able to establish a close rapport with the Trades Council and it was only a matter of time before ILP members were elected, in their capacity as trade union leaders, to the Executive Committee. In 1895, for example, Sutton himself together with John Harker and the old Social Democrat George Tabbron took their places on the Committee of the Trades Council. More socialists were to follow in later years. Even before this, though, the convergence of ILP and Trades Council interests could be seen in joint election work. In 1894 the two bodies co-operated in the School Board Elections under the auspices of a United Labour Party, whilst the seven ILP candidates for the municipal-council elections in the Manchester area were all given the official blessing of the Trades Council. ${ }^{89}$

By the middle of the 1890's, then, there was something of a "good neighbour" policy operating between the two bodies. It remained to be seen though, whether this could be translated into a more concrete political formation that would embody the principle of independence. Progress towards this was certainly assisted by the failure of the Liberal initiative, which removed a considerable obstacle from the path towards a labour alliance, and by Blatchford's increasing attention in his journalism to national rather than Manchester issues. By the later 'nineties the ILP was able to further Clause Two of its Constitution by making a bid to become a really effective electoral organisation. As early as 1893 the party had elaborated an election programme of great comprehensiveness. The Municipal Programme, as it was called, detailed a host of reforms in the administrative and political structures of local government. It owed much, in fact, to previous SDF schemes for creating a more civilised environment

87 Colliery Workman's Times, 9 December 1893.

88 Manchester Guardian, 2 November 1894.

89 Manchester and Salford Trades Council, Annual Report, 1896; Manchester Guardian, 2, 3, and 20 November 1894; Clarion, 27 October; Pankhurst, The Suffragette Movement, p. 119. 
for working people in the big industrial cities: the abolition of slum dwellings and provisions for the building of healthier homes, cheap transport for workmen, an eight-hour day for Corporation employees, pensions for those employed by the Municipality, equal pay for men and women, and free food and clothing for needy schoolchildren were among the more prominent demands. The programme was designed to give local authorities greater power to improve the environment, and this involved sweeping away some of the obstacles to change such as the Aldermanic Bench, the rating system and the Poor Law. As such the ILP's Municipal Programme went much farther than the Liberals' response to it of the following year, and could therefore be seen either as a root-and-branch reform of the foundations of local government or simply as a series of useful changes, any one of which would bring some immediate improvement in social conditions. ${ }^{90}$

The Municipal Programme, then, served as a manifesto for a wide range of voters. To complement these ideological initiatives, however, the ILP needed to equip itself with an electioneering machine and, in this context, the administrative changes set in motion by the party secretary Joe Nuttall from about 1896, and completed by his successor Thomas Gunning shortly after 1900, formed an important part of ILP electoral development. ${ }^{91}$ Not that the changes brought about any immediate increase in socialist representation; in the later 'nineties the ILP could support only two City Councillors in Manchester (Sutton and Brocklehurst) and normally one (G. T. Jackson) in Salford; as such it never seemed likely to become an independent electoral force of any real power. More significant, however, was the fact that Nuttall's and Gunning's reforms created a party machine that, given the opportunity, could be adapted to form the basis of an independent working-class party. This indeed happened when the Manchester and Salford Labour Representation Committee was created in 1903.

The formation of this party, which re-created the labour unity that had been temporarily apparent in 1891 , owed something therefore to the efforts of the ILP. Following the failure of Liberal reforms in the mid 'nineties, perhaps it was only a matter of time before the organised working class of Manchester kicked over the traces of its Liberal tutelage and became independent, but the ILP's coaxing clearly had some effect. Its willingness, for example, to arrange ad hoc electoral alliances with other labour forces prepared the way for a more permanent relationship, especially since the

90 Workman's Times, 5 August 1893.

${ }^{91}$ Manchester, August and December 1900. 
co-operation had often been successful. In 1900 the United Workers' Municipal Election Committee, organised by Tom Gunning, helped to achieve harmony between the two wings of the labour movement, whilst the launching by the ILP of a monthly newspaper, Manchester, in 1899 served to provide a forum for labour interests in the city. ${ }^{92}$ And all this time ILP members were gaining prominence in the Trades Council: by the early 1900's Sutton, Harker and Tabbron had been joined on the Executive Committee by Tom Fox, Joe Nuttall and A. A. Purcell, so that left-wing resolutions received some encouragement from the top. ${ }^{93}$ But it is doubtful whether the ILP could have precipitated such an effective labour alliance by itself. Favourable external developments were, in fact, of vital importance in explaining why the organised labour movement of Manchester should embrace the principle of independent labour representation at the very beginning of the twentieth century.

Of particular significance in this respect was the striking degree of solidarity that developed among workers at this time and which largely derived from the feeling that labour was under attack. Threats to the working-class position were seen, for instance, in the new Education Act, which had removed schools from direct popular control. Displeasure over this legislation was soon compounded by adverse decisions in the Taff Vale litigation, which was the prominent issue in a mass demonstration organised by the Trades Council on May Day 1902. Held in Gorton Park, the demonstration called for new measures to define the legal status of trade unions as well as demanding a scheme for old-age pensions and improvements in local housing conditions. ${ }^{94}$ In the following year these problems, still unresolved, were augmented by the publication of Conservative proposals on Tariff Reform - "a fresh attempt to grind the poor by the Food Tax", as G. D. Kelley described them. ${ }^{95}$ In the face of what seemed like a concerted assault on working-class living standards a solution was increasingly sought through labour representation, which, more than at any previous time, became the overriding slogan of the labour movement, bringing together socialists and non-socialists, craftsmen and

92 In 1897 the Trades Council-ILP alliance had returned Nuttall and Brocklehurst to the School Board, Manchester and Salford Trades Council, Annual Report, 1897. The journal Manchester (from 1901 The Social Reformer) was launched in the summer of 1899 to promote the idea of municipal socialism, and in October 1900 the United Workers' Municipal Election Committee arose out of discussions held the previous July among a wide range of local working-class groups.

93 Manchester and Salford Trades Council, Annual Reports, 1900-06.

94 Ibid., 1902.

95 Ibid., 1903. 
unskilled. Taff Vale was the crucial turning-point, arousing the collective anger of the organised workers in a way that, as Kelley himself admitted, could "only be appeased by the return of Labour men to the House of Commons". 96

It is interesting to note, moreover, that the Trades Council had become affiliated to the national Labour Representation Committee in 1901, although it had not been prepared to participate in the formation of a local LRC. The non-socialist Kelley attended the national LRC conferences of 1901 and 1902 as the Manchester delegate and seemed unwilling to become involved with the socialist element, a posture which suggested that there was still some distance between the two camps despite the joint electoral enterprises of previous years. From 1903, though, the situation changed radically. In that year the Council resolved that "the time is now opportune for Labour to assert itself by advancing candidates at the next General Election for the purpose of securing Direct Labour Representation in the House of Commons and at least 2 constituencies in Manchester and one in Salford be selected". ${ }^{97}$ The Council then proceeded to nominate John Harker and G. D. Kelley, thus dividing the proposed candidatures between the socialist and non-socialist elements. From this point it was a short step to the formation in the summer of 1903 of a local LRC comprising 55 trade societies from the Trades Council together with 5 ILP and 2 SDF branches. ${ }^{98}$ It was through this body that the ILP's party structure and programme, evolved during the 1890's, became the structure and programme of the new local labour party, whose principal officers were all ILP men.

The final rejection of Lib-Labism by the skilled elite of the Manchester working class was clearly embodied in the attitude of G. D. Kelley. When Kelley eventually joined the Labour Party at some point between late 1903 and early 1904, he severed an attachment to the Liberals that had been formed some half a century earlier when he was beginning to make his way in the service of his union. As a self-educated artisan Kelley had spent most of his adult life as an official of the Lithograph Printers' Society; he had been its general secretary since 1878 and the secretary of the Manchester and Salford Trades Council since 1881, always behaving as an impeccably respectable radical, pursuing the goal of labour representation within the framework of a populist Liberal movement. He himself had been relatively successful, acquiring prestige in Manchester as a City Councillor and JP by the 1890's. But the failure of the Liberal Party as a vehicle for general

${ }^{96}$ Ibid.

97 Ibid.

98 Justice, 8 August 1903. 
working-class advancement had become steadily more apparent to him. First the Labour Electoral Association had been suffocated through lack of encouragement, and then the MLU had turned its back on labour representation, whilst repeated electoral failures had left the party in no position to defend the interests of working men by the early 1900's. Kelley was forced to admit that the Liberals had been unable to do "all a workman had a right to expect from them", 99 and was left to inveigh against the "rich men and great landlords" of the Tory Party - "a party of privilege and monopoly"100 - as it attacked the foundations of the trade-union movement. It was hardly surprising that he was to be found by 1903, when the full force of the Taff Vale judgement hit the labour movement, pleading in his Trades Council report for "a sinking of petty differences, whether of personal feeling or political creed [...] to aim for the goal of labour representation". ${ }^{101}$ It was more or less at this point that G. D. Kelley left the Liberal Party and joined forces with his former adversaries, the socialists of the ILP, in the newly fashioned Manchester and Salford LRC. No doubt many members of the trade societies which became affiliated at this time shared Kelley's views and welcomed the opportunity to articulate their interests through a new organisation fully committed to working-class advancement. For Kelley himself the change of allegiance was timely, for it brought him the prize that previously had eluded his grasp: within two years he was a Labour Member of Parliament for Manchester.

The advance of the Manchester and Salford Labour Party over the next few years was sufficiently rapid to confirm the support for such an organisation and thereby to vindicate the labourist tendencies within the ILP since the mid 'nineties. The party quickly acquired the broad-bottomed appearance of what, in later years, came to be called a "model party" by Labour organisers; that is to say it managed to blend the trade-union interest, which assured extensive financial support, with the ideological vision of ILP socialism. Together these gave the party the necessary endowments with which to challenge for power in municipal politics.

The Manchester Labour Party opened its doors to trade unions, trades councils, co-ops, socialist societies and "all other Labour or socialist organisations that are willing to work for the objects and conform to the

99 Cited in Bather, "A History of the Manchester and Salford Trades Council". op. cit., p. 166.

100 Manchester and Salford Trades Council. Annual Report, 1903.

101 Ibid. 
rules of this Committee and the National Labour Party". ${ }^{102}$ The backbone of the party was its trade-union affiliations, numbering over 17,000 by 1910 , and this naturally gave the union element a preponderance on the Committee. But a generous representation of two delegates for every 200 members (and three for higher membership) meant that the socialist societies were assured of an important influence in the Labour Party's controlling counsels. ${ }^{103}$ This influence was in fact enshrined in the broad, socialistic programme by which the party identified itself for electoral purposes: based upon the ILP Municipal Programme of 1893, but well larded with practical industrial issues of special concern to trade unionists, the Labour programme ranged from the nationalisation of land and railways, through free trade and free education from elementary to university level, to workmen's compensation, the eight-hour day and "national efficiency". ${ }^{104}$ Moreover, a highly centralised and efficient system of electoral management produced some promising results quickly in municipal politics. By 1910, for example, Labour could mobilise 15 representatives in the Manchester City Council and never fell below this strength before the First World War. ${ }^{105}$ The foundations were thus established for the Labour Party's speedy advance after the war as the natural party of the working class in Manchester.

In considering the development of the ILP in Manchester and Salford we are faced with a process that was at once less dramatic and more gradual than that of Bradford. There was an obvious social and economic difference between the two cities in that the class polarisation of Manchester - well established in spatial terms by the end of the nineteenth century was hardly evident at all in Bradford before 1914. Paradoxically, though, this does not seem to have made for more intransigent political relationships in Manchester, as might have been expected. On the contrary, it was Bradford which witnessed an intense confrontation in its political development at the beginning of the 1890's. Bradford's social admixture and its (consequent) strong popular nonconformity appears to have engendered in the mind of the Liberal manufacturing elite a sense of confidence about its political hegemony which caused them to oppose the

102 Manchester and Salford Labour Representation Committee, Annual Report, 1906. Manchester Public Library.

103 Ibid., 1905, 1908, 1910 and 1912

104 Ibid.. 1906; Cotton Factory Times, 6 November 1903.

105 Between 1906 and 1914 the Labour Party representation in Manchester City Council (including ILP members) was as follows: $1906-11 ; 1907-11 ; 1908-10 ; 1909-8 ; 1910$ - 10;1911 - 14;1912 - 16;1913 - 16:1914 - 15. During the same period Conservative strength ranged from 38 to 57 and Liberal from 19 to 33 . This information kindly supplied by the Local History Library, Manchester Public Library. 
advocates of independent labour representation with great vigour. Between 1890 and 1892 the class nature of the Liberal Party was fully exposed and credibility in its function as a popular movement destroyed; as Reynolds and Laybourn point out, "support for Liberalism had been eroded among the most effectively politically motivated members of some of the most powerful craft unions." ${ }^{106}$ It was this that enabled the ILP to take control of the local labour movement and lead it towards independence, ousting from positions of influence the traditional Lib-Lab leadership.

In Manchester the same process was a far more protracted affair. There was never any point at which the ILP was able to act as the complete embodiment of labour interests: instead, the party had to settle for the role of a self-sufficient organisation within the working-class movement. The internal contradictions of the Liberal-Labour relationship were resolved without any significant recourse to socialism, indeed the inability of the Liberals to make the most of their potential support - a failure compounded of social hauteur and lack of political insight - emerged as the crucial factor in this equation. Once the organised working-class movement had recognised that Lib-Labism was a blind alley, the ILP was able to make a distinctive contribution to the shaping of a third political force in Manchester and Salford. In the form of the Labour Party it sought to replace the ethic of individual improvement for the working man, which had been so characteristic of Liberalism, by the principle of improvement for the class as a whole.

106 Reynolds and Laybourn, "The Emergence of the Independent Labour Party in Bradford", pp. 336-37. 


$$
\text { APPENDIX }
$$

\section{I}

MAIN OCCUPATIONS SOUTH-EAST LANCASHIRE, 1901

$\begin{array}{lrrrr}\begin{array}{l}\text { Percentage of workforce } \\ \text { employed in }\end{array} & \text { Manchester } & \text { Salford } & \text { Oldham } & \text { Bolton } \\ \text { Textiles } & 8 & 14 & 42 & 38 \\ \text { Mining } & 0 & 1 & 1 & 3 \\ \text { Chemicals } & 1 & 0 & 0 & 0 \\ \text { Metal and engineering } & 9 & 8 & 18 & 12 \\ \text { Building } & 7 & 7 & 5 & 5 \\ \text { Transport } & 5 & 5 & 9 & 3 \\ \text { Food and drink } & 9 & 4 & 4 & 6 \\ \text { Commerce and professions } & 7 & 7 & 5 & 5 \\ \text { General trades and } & & & & \\ \quad \text { miscellaneous } & 53 & 54 & 17 & 27\end{array}$

Source: Census of England and Wales.

II

PERCENTAGE OF THE LIBERAL VOTE IN MANCHESTER AREA, 1885-1900

$\begin{array}{lcccc} & 1885 & 1892 & 1895 & 1900 \\ \begin{array}{l}\text { Manchester } \\ \text { East }\end{array} & 45.0 & 48.0 & 46.1 & 36.6 \\ \quad \text { North } & 43.2 & 51.8 & 52.8 & 50.1 \\ \text { North-East } & 40.0 & 49.3 & 48.4 & 45.5 \\ \quad \text { North-West } & 46.7 & 47.4 & 41.4 & 35.2 \\ \text { South } & 54.8 & 51.1 & 49.6 & 42.9 \\ \quad \text { South-West } & 46.1 & 51.0 & 46.7 & 37.4 \\ \text { Salford } & & & & \\ \quad \text { North } & 48.7 & 52.0 & 49.9 & 44.5 \\ \text { South } & 50.3 & 49.7 & 49.9 & 41.5 \\ \quad \text { West } & 51.9 & 49.7 & 49.4 & 44.1 \\ \text { Gorton } & 60.5 & 51.1 & 42.1 & 47.3 \\ \text { Stretford } & 51.1 & 44.3 & \text { Uncontested } & 39.4 \\ & & & \text { by Liberals } & \end{array}$

Source: Dod's Parliamentary Companion. 